\title{
Postoperative anterior uveitis in a patient submitted to combined treatment with cataract surgery and iStent inject $\circledR$. How to manage?
}

Uveíte anterior no pós-operatório de facectomia combinada

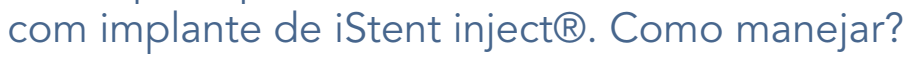

Ana Flávia Lacerda Belfort ${ }^{1}$ (D) Brunelle Francino Nunes ${ }^{2}$, Wilton Feitosa de Araújo² (D), Cibele Lima Belico Suzuki ${ }^{3}$ (D) Clarice Freire Dayrell de Souza ${ }^{4}$ [1) Emílio Rintaro Suzuki Júnior ${ }^{5}$ (])

Department of Glaucoma, Santa Casa de Misericórdia de Belo Horizonte, Belo Horizonte, MG, Brazil. ¿Department of Posterior Segment, Santa Casa de Misericórdia de Belo Horizonte, Belo Horizonte, MG, Brazil. ${ }^{3}$ Instituto de Olhos Pampulha, Belo Horizonte, MG, Brazil.

${ }^{4}$ Department of Glaucoma, Centro Oftalmológico de Minas Gerais, Belo Horizonte, MG, Brazil. ${ }^{5}$ Pontifícia Universidade Católica de Minas Gerais, Betim, MG, Brazil.

Keywords:

Glaucoma, open-angle; Uveitis, anterior; Inflammation; Cataract extraction; Minimally invasive surgical procedures

Descritores:

Glaucoma de ângulo aberto; Uveíte anterior; Inflamação;

Extração de catarata; Procedimentos cirúrgicos minimamente invasivos

Received on: Aug 27,2021

Accepted on: Oct 6, 2021

Corresponding author: Ana Flávia Lacerda Belfort Avenida Alfredo Balena, 596 - Centro Zip code: 30130-100 - Belo Horizonte, MG, Brazil

E-mail: anaflaviabelfort@gmail.com

Institution: Centro Oftalmológico de Minas Gerais, Belo Horizonte, MG, Brazil.

Conflict of interest: no conflict of interest.

Financial support: inancial support for this work.

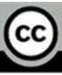

Copyright (C2022

\section{ABSTRACT}

Minimally invasive glaucoma surgeries are surgical treatment alternatives for glaucoma aimed at reducing intraocular pressure with a better safety profile compared to traditional trabeculectomy. However, in spite of less invasive techniques, complications may develop in any surgical procedure. To the best of our knowledge, this is the first case report of anterior uveitis following combined treatment with cataract surgery and iStent inject ${ }^{\circledR}$ which addresses the management of postoperative inflammation.

\section{RESUMO}

As cirurgias minimamente invasivas para glaucoma consistem em uma opção de tratamento cirúrgico para glaucoma, a qual promove redução da pressão intraocular com melhor perfil de segurança do que a trabeculectomia. Todavia, complicações são inerentes à realização de procedimentos cirúrgicos, apesar do uso de técnicas menos invasivas. Este é o primeiro relato que apresenta um caso de uveíte anterior após cirurgia combinada de catarata e iStent inject ${ }^{\circledR}$, além de orientações quanto ao manejo do quadro inflamatório. 


\section{INTRODUCTION}

Glaucoma is the leading cause of irreversible blindness worldwide. It is estimated that 111.8 million people will suffer from primary open-angle or angle-closure glaucoma in 2040.(1) Intraocular pressure (IOP) lowering eye drops are often used as the first line treatment. However, their effectiveness is limited due to factors such as poor compliance, ocular surface diseases, side effects and medication costs, which should be accounted for in treatment indication by the attending physician. ${ }^{(2)}$ Minimally invasive glaucoma surgeries (MIGS) are surgical procedures aimed at reducing IOP with greater safety relative to traditional filtering surgeries. ${ }^{(3)}$ iStent inject ${ }^{\circledR}$ is a second generation trabecular micro-bypass device consisting of two heparin-coated titanium stents built into an injector. The goal is to access the Schlemm's canal via an ab internal approach and create a patent bypass for enhanced aqueous outflow. The safety of iStent inject ${ }^{\circledR}$ has been demonstrated in several studies. ${ }^{(4,5)}$ However, reports addressing the management of major complications, such as anterior synechiae, hyphema, anterior uveitis, stent migration and device malposition, are scarce. ${ }^{(1,5,6)}$ Although uncommon, surgeons must be aware of the fact that these could be the first manifestations of a systemic disease.

\section{CASE REPORT}

A 59-year-old Caucasian woman presented for open-angle glaucoma follow-up. The condition had been well controlled for 5 years using a combination of latanoprost and timolol maleate. Medical record data were unremarkable, except for previous radial keratotomy. Refractive error was $+4.00-2.50 \times 50$ in the right eye and $+4.00-2.50 \times 180$ in the left eye, with best-corrected visual acuity of 20/70 (logMAR of 0.54) in both eyes. She had moderate nuclear cataract, radial keratotomy scars and an average IOP of 15 $\mathrm{mmHg}$. Dilated fundus examination revealed a cup/disc ratio of 0.7 in both eyes (Figures $1 \mathrm{~A}$ and $1 \mathrm{~B}$ ) and no significant macular or peripheral abnormalities. Standard automated perimetry (Octopus ${ }^{\circledR} 300$ ) performed using the TOP strategy was normal and central corneal thickness was 592 $\mu \mathrm{m}$ and $599 \mu \mathrm{m}$ (right and left eyes respectively). Cataract surgery combined with iStent inject ${ }^{\circledR}$ was indicated. In the right eye, surgery was uneventful. Immediate postoperative IOP was $12 \mathrm{mmHg}$ and topical moxifloxacin, dexamethasone and ketorolac trometamol were prescribed. On the seventh day of the postoperative period, IOP was $24 \mathrm{mmHg}$, stents were well positioned, and other ocular findings were unremarkable. Intraocular pressure elevation secondary to the use of corticosteroids was suspected. Dexamethasone instillation was titrated to twice daily and IOP levels returned to $12 \mathrm{mmHg}$.

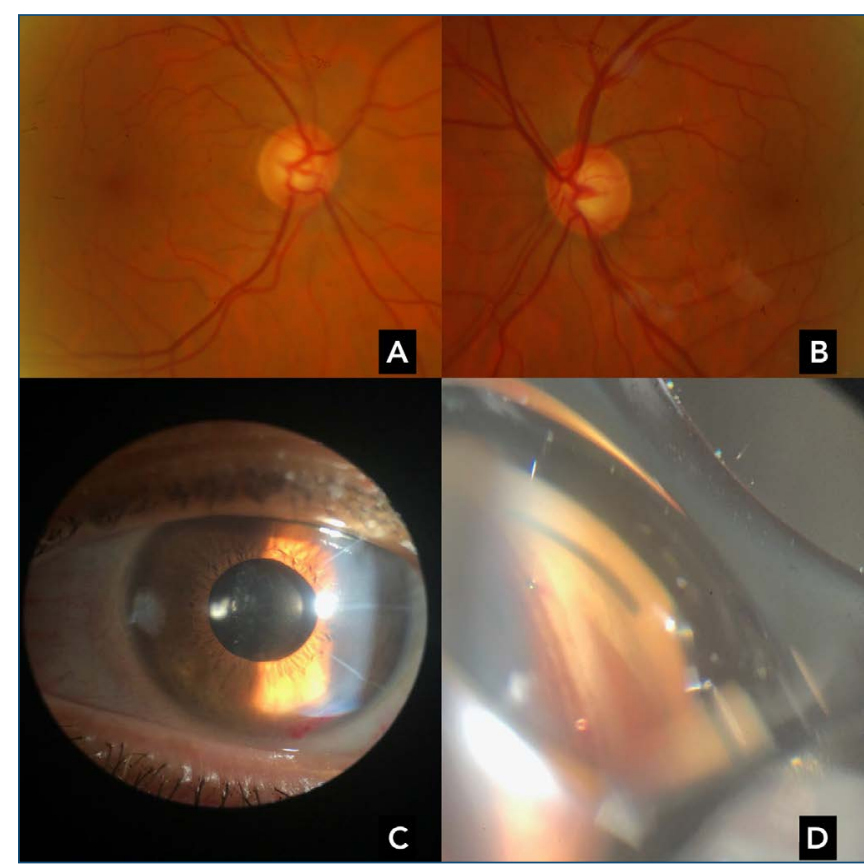

Figure 1. images that illustrate the patient's clinical case. (A) and (B) Bilateral enlarged disc cupping of the optic nerves. (C) Mild hyphema on the first postoperative day after left eye surgery. (D) Gonioscopic view after successful implantation of Istent Inject during surgery.

In left eye, surgery was also uneventful. The day after surgery, mild hyphema (Figure $1 \mathrm{C}$ ) was noted, IOP was 9 $\mathrm{mmHg}$ and the same treatment regimen was prescribed. However, on the third postoperative day the patient developed a significant inflammatory reaction in the anterior chamber and IOP increased to $42 \mathrm{mmHg}$, with no abnormalities on dilated fundus examination. Tropicamide $(10 \%)$ every 6 hours, a combination of timolol maleate and brimonidine tartrate (0.5\% and $0.2 \%$ respectively) every 12 hours and oral acetazolamide (250 mg) every 6 hours were prescribed. Within two days, IOP dropped to $11 \mathrm{mmHg}$, but the inflammatory reaction persisted. Infectious and rheumatological causes were investigated and ruled out. On the seventh postoperative day, the patient reported improvement in visual acuity, the inflammatory reaction had subsided and IOP was $11 \mathrm{mmHg}$. Topical dexamethasone and acetazolamide were gradually discontinued over the course of 3 weeks and a combination of timolol and brimonidine prescribed until complete recovery. One month after surgery, best corrected visual acuity was 20/25 in the right eye and 20/40 in the left eye, there were no signs of inflammation and IOP was low (9 and $10 \mathrm{mmHg}$, right and left eye respectively), with no need of topical medication. 


\section{DISCUSSION}

Minimally invasive glaucoma surgeries are surgical procedures aimed at reducing IOP with greater safety relative to traditional filtering surgeries. ${ }^{(1)}$ Although the safety of iStent inject ${ }^{\circledR}$ has been demonstrated in several studies, ${ }^{(2,3)}$ management of related complications has seldom been reported in literature. To the best of our knowledge, this is the first publication to describe the management of postoperative anterior uveitis in a patient submitted to combined treated with cataract surgery and iStent inject ${ }^{\circledR}$. Although uncommon, the literature suggests uveitis occurs in $5.7 \%$ of cases, ${ }^{(5)}$ and that patients with a history of uveitis and African Americans tend to develop more severe inflammation. ${ }^{\left({ }^{6}\right)}$

In cases with postoperative iridocyclitis, a detailed clinical history must be obtained and a complete eye examination performed, including IOP measurement, gonioscopy, dilated fundus examination and vitreous cell assessment. Endophthalmitis should also be ruled out, given the severity of the condition. Anterior toxic syndrome, viscoelastic remnants in the anterior chamber, and remaining cortex should also be excluded. Laboratory workup may be required to investigate secondary causes of uveitis, as this may be the first manifestation of a systemic disease triggered by surgical trauma. In our service, comprehensive initial assessment includes complete blood count, screening for sexually transmitted diseases (venereal disease research laboratory, VDRL), fluorescent treponemal antibody absorption (FTA-ABS), Manteaux tuberculin skin test, antinuclear factor, rheumatoid factor and HLA-B27 testing, p-ANCA and c-ANCA tests and chest radiography. Polymerase chain reaction tests for detection of viruses of the herpes family (Herpes simplex virus, Varicella-zoster virus, Cytomegalovirus and Epstein-Barr virus) should also be considered. If a specific disease is suspected, further investigation is warranted (radiographic assessment of joints with inflammation, angiotensin-converting enzyme level measurement, etc.).

In patients with no suspicious systemic or ocular signs, treatment with steroids and topical cycloplegic agents given according to the severity of the inflammatory impairment is recommended. Intraocular pressure should also be controlled with topical and systemic medications, depending on IOP levels. iStent inject ${ }^{\circledR}$ is a heparin-coated titanium device. Therefore, incompatibility issues are unlikely. Still, it could be argued that the unexpected inflammatory response in the case reported was triggered by iStent inject ${ }^{\circledR}$. In any case, the patient responded well to treatment and achieved complete resolution of the intraocular inflammation and appropriate control of the elevated IOP. No detectable sequelae of this benign postoperative iridocyclitis remained.

\section{REFERENCES}

1. Pillunat LE, Erb $C$, Jünemann AG, Kimmich F. Micro-invasive glaucoma surgery (MIGS): a review of surgical procedures using stents. Clin Ophthalmol. 2017;11:1583-1600. Erratum in: Clin Ophthalmol. 2018;12:287

2. Hengerer FH, Auffarth GU, Riffel C, Conrad-Hengerer I. Second-generation trabecular micro-bypass stents as standalone treatment for glaucoma: a 36-month prospective study. Adv Ther. 2019;36(7):1606-17.

3. Guedes RA, Gravina DM, Lake JC, Guedes VM, Chaoubah A. One-year comparative evaluation of iStent or iStent inject implantation combined with cataract surgery in a single center. Adv Ther. 2019;36(10):2297810

4. Tham YC, Li X, Wong TY, Quigley HA, Aung T, Cheng CY. Global prevalence of glaucoma and projections of glaucoma burden through 2040: a systematic review and meta-analysis. Ophthalmology. 2014;121(11):208190.

5. Samuelson TW, Sarkisian SR Jr, Lubeck DM, Stiles MC, Duh YJ, Romo EA, et al.; iStent inject Study Group. Prospective, randomized, controlled pivotal trial of an ab interno implanted trabecular micro-bypass in primary open-angle glaucoma and cataract: two-year results. Ophthalmology. 2019;126(6):811-21.

6. Neatrour K, McAlpine A, Owens TB, Trivedi RH, Poole Perry LJ. Evaluation of the etiology of persistent iritis after cataract surgery. J Ophthalmic Inflamm Infect. 2019;9(1):4. 